
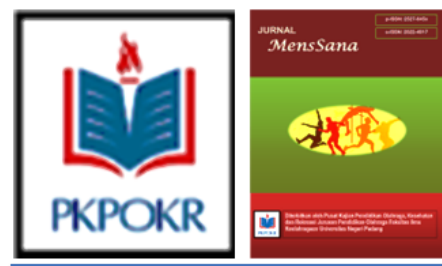

Vol. 4, No. 2; Tahun 2019

ISSN : 2527-645X, E-ISSN: 2622-4917

Penerbit:

Pusat Kajian Pendidikan Olahraga, Kesehatan dan Rekreasi,

Jurusan Pendidikan Olaharga, Fakultas Ilmu Keolahragaan, Universitas Negeri Padang

\title{
PENERAPAN METODE DRILL UNTUK MENINGKATKAN KEMAMPUAN BIDDING DAN PLAYING MINI BRIDGE SISWA SD NEGERI O04 RAMBAH SAMO
}

\author{
Debby Indah ${ }^{1}$, Hendri Mulyadi ${ }^{2}$ \\ ${ }^{12}$ Program Studi Pendidikan Jasmani Kesehatan dan Rekreasi, STKIP Rokania, \\ Jln. Raya Pasir Pengaraian KM 15 Langkitin Kecamatan Rambah Samo \\ Kabupaten Rokan Hulu Riau Indonesia 28565 \\ E-mail: baisangka@gmail.com ${ }^{1}, \underline{\text { hendrimulyadi999@gmail.com }}{ }^{2}$
}

\begin{abstract}
Abstrak
Masalah penelitian adalah rendahnya kemampuan bidding dan playing mini bridge siswa SD Negeri 004 Rambah Samo. Penelitian ini bertujuan meningkatkan kemampuan bidding dan playing mini bridge siswa SD Negeri 004 Rambah Samo dengan penerapan metode drill. Metode yang digunakan penelitian eksperimen semu berupa memberikan perlakukan latihan drill yang dirangkum dalam program latihan dengan menggunakan modul pembelajaran mini bridge. Data penelitian dianalisa menggunakan t-tes pada taraf signifikan 5\%. Hasil penelitian menunjukkan, nilai pretest kemampuan bidding dan playing mini bridge siswa sebesar 53,75 meningkat menjadi nilai posttest sebesar 77,19 setelah memberikan perlakuan penerapan metode drill. Hasil analisa data diperoleh $t$ hitung sebesar 18,486 sedangkan t tabel sebesar 1,753. Berarti, penerapan metode drill memiliki pengaruh yang signifikan terhadap kemampuan bidding dan playing mini bridge. Disimpulkan, terjadinya peningkatan perlakuan penerapan metode drill terhadap kemampuan bidding dan playing mini bridge siswa SD Negeri 004 Rambah Samo yaitu sebesar $23,44 \%$.
\end{abstract}

Kata Kunci: Metode Drill, Bidding, Playing Mini Bridge

\section{The Application of Drill Methode to Increase the Ability of Mini Bridge Bidding and Playing in Elementary School Student of SD Negeri 004 Rambah Samo.}

\begin{abstract}
The problem of research, The ability of mini bridge bidding and playing is low for the Elementary School student of SD Negeri 004 Rambah Samo. The meaning of this research to increase the ability of mini-bridge bidding and playing with drill methode application. The methode used appearance experimental observation, giving drill excercises combined with training program that use mini-bridge learning modul. The research data analised with $t$-test with rank of significant $5 \%$. The research result shows that the pre-test value of mini-bridge bidding and playing is 53.75 higher, and post-test value became 77.19 after applied drill methode. The research data shows that, the t-count is 18.486, while t-table is 1,753 . Meaningly, the aplication of drill methode have significantly influence against bidding and playing ability of mini-bridge. In Conclusion, that there is inscreasing of drill methode aplication against bidding and playing ability of mini-bridge in Elementary School student of SD Negeri 004 Rambah Samo, namely $23.44 \%$.

Keywords: Drill Methode, Bidding, Mini Bridge Playing.

\section{PENDAHULUAN}

Bridge adalah intelligence sport, dimana permainan bridge melibatkan kemampuan menganalisis, kecepatan berfikir, kerjasama dan

keberanian menentukan suatu keputusan. Hal ini diperkuat oleh pendapat Asbi (2010) yang menyatakan, bahwa "Olahraga bridge adalah permainan kartu yang mengandalkan
\end{abstract}



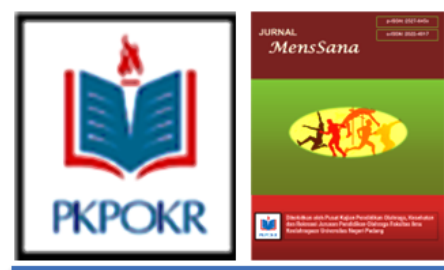

Vol. 4, No. 2; Tahun 2019

ISSN : 2527-645X, E-ISSN: 2622-4917

Penerbit:

Pusat Kajian Pendidikan Olahraga, Kesehatan dan Rekreasi,

Jurusan Pendidikan Olaharga, Fakultas Ilmu Keolahragaan, Universitas Negeri Padang

kemampuan berfikir, analisis, kosentrasi, keberanian, kerjasama, dan ketekunan untuk mengambil keputusan dalam menetapkan suatu kontrak main dan memainkannya agar dapat mencapai kontrak". Berarti, kemampuan kognitif dan afektif sangat dibutuhkan dalam pelaksanaan permainan bridge.

Mempermudah permainan bridge untuk tingkat pemula dikembangkan melalui permainan mini bridge. GABSI (2015) mengemukan "Mini Bridge menyederhanakan bagian bidding dari permainan bridge". Sugeng dalam Jurnal Pendidikan Jasmani Indonesia (2010) menyatakan permainan mini bridge adalah permainan yang dimainkan oleh 4 orang siswa yang saling berpasangan utara berpasangan dengan selatan dan timur berpasangan dengan barat dalam satu meja dengan menggunakan satu pack kartu joker (remi).

Berarti, permainan mini bridge merupakan permainan yang dimainkan oleh 4 orang dengan menggunakan cara penawaran yang lebih mudah menuju permainan bridge yang sebenarnya.

Penelitian yang peneliti lakukan sebelumnya mengenai aplikasi pendekatan active learning terhadap kemampuan permainan mini bridge siswa kelas IV SD Negeri 004 Rambah Samo diperoleh hasil terjadinya peningkatan kemampuan permainan mini bridge siswa, namun secara individu maupun kelompok kemampuan permainan mini bridge siswa dikategorikan rendah. Permasalahan rendahnya kemampuan siswa dalam permainan bridge terdapat pada bidding (proses lelang) dan playing (bagian permainan). Dimana, siswa tidak memahami cara menentukan kontrak dalam bidding untuk menentukan dan memperoleh jumlah trik kemenangan yang dicapai dalam playing mini bridge.

Penawaran (bidding) merupakan suatu proses dalam menetapkan kontrak terhadap kartu pegangan sesuatu ketentuan penawaran. Proses lelang (action bidding) dilakukan setelah kartu dibagikan, menghitung jumlah pegangan kartu dan berkompetisi siapa yang menjadi declarer. Selanjutnya, declarer melalui analisa pegangan kartu dan memperhatikan simbolsimbol yang dikemukakan lawan main selama proses lelang menetapkan dimana kontrak permainan dilakukan. Setelah menetapkan kontrak main, dilanjutkan melakukan proses permainan (playing).

Proses permainan (playing) merupakan suatu proses memainkan kartu pegangan untuk memenangkan kontrak atau trick yang ditentukan. Trick merupakan suatu putaran yang terdiri dari empat kartu, setiap pemain mengeluarkan selembar kartu. Permainan berurutan se-arah jarum jam. Pemain yang memainkan kartu paling tinggi memenangkan trick tersebut. Si pemenang trick mengeluarkan kartu pertama pada trick berikutnya dan setiap pemain wajib mengeluarkan suit (warna kartu) yang sama dari yang diminta oleh pemain yang mengeluarkan kartu pertama. Pihak yang menang meletakkan kartu secara vertikal (portrait) dan jika kalah meletakkan kartu secara horizontal (landscape).

Mencapai tingkat keterampilan dalam pembelajaran ditentukan oleh suatu metode, salah satunya metode drill/latihan. Syaiful\&Aswan Zain (dalam Istarani, 2012) mengemukakan metode latihan yang disebut juga metode training merupakan suatu cara mengajar yang baik untuk menanamkan kebiasaan-kebiasaan tertentu dalam memperoleh suatu ketangkasan, ketepatan, kesempatan dan keterampilan.

Hardianto (2012: 139) menyatakan "Metode latihan merupakan metode mengajar, dimana siswa melaksanakan kegiatan latihan agar siswa memiliki ketegasan atau keterampilam yang lebih tinggi dari apa yang telah dipelajari”. Disimpulkan, metode drill merupakan cara mengajar menanamkan kebiasaan tertentu melalui proses latihan untuk memperoleh suatu keterampilan dari apa yang dipelajari.

Rostiyah (dalam Istarani, 2012) menyatakan metode drill banyak digunakan untuk pelajaran olahraga. Dalam hal ini banyak cabang olahraga yang melakukan latihan khusus dan teratur, serta pengawasan dari trainer yang baik.

Hardianto (2012: 139) mengemukakan tujuan dari metode latihan, diantaranya: (1) meningkatkan keterampilan motoris seperti menghafal kata, menulis, mempergunakan alat, membuat suatu bentuk atau melaksanakan olahraga, (2) mengembangkan kecakapan intelek, seperti membagi, mengalikan, menjumlah, mengurangi, menarik akar, menghitung, menggunakan tanda baca dan lain 


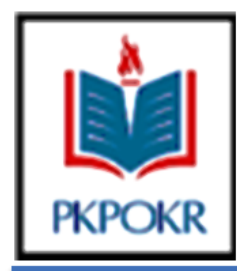

sebagainya, menghubungkan antara suatu keadaan hal lain seperti hubungan sebab akibat, penggunaan lambang dan simbol dalam peta, (4) dapat menjadikan pengetahuan dan pemahaman siswa menjadi lebih baik.

\section{METODE}

Penelitian ini menggunakan metode quasi eksperimen. Maolani (2015) menyatakan "Penelitian quasi eksperimental boleh digunakan bila penelitian eksperimental sungguhan tidak mungkin dapat dilaksanakan, karena rancangan penelitian quasi eksperimental tidak dapat memberikan kontrol penuh, sangatlah penting bagi seseorang peneliti untuk menyadari variabel mana dalam rancangan tidak dapat dikontrol sempurna". Berarti, penelitian ini memberikan perlakuan metode drill dalam meningkatkan kemampuan bidding dan playing mini bridge sesuai modul pembelajaran disetiap pertemuan.

Penelitian ini dilaksanakan dari tanggal 23 Maret sampai dengan 29 Juni 2019 di SD Negeri 004 Rambah Samo. Subjek penelitian ini adalah siswa SD Negeri 004 Rambah Samo yang mengikuti kegiatan pembinaan mini bridge yaitu sebanyak 16 orang. Instrument yang digunakan berupa tes dalam bentuk soal mengenai bidding dan playing mini brigde. Indikator keberhasilan peneltian ini adalah daya serap siswa secara individu 75\% (Depdiknas, 2003). Daya serap siswa secara individu dilihat dari peningkatan kemampuan bidding dan playing mini bridge siswa dalam bentuk tes soal. Data yang diperoleh diolah secara manual mempergunakan teknik analisa data uji beda t-tes (Sudjana,1992).

\section{HASIL DAN PEMBAHASAN}

\section{Hasil Penelitian}

Data pretest kemampuan bidding dan playing permainan mini bridge siswa SD Negeri 004 Rambah Samo yang diperoleh pada tanggal 23 Maret 2019 tertera pada tabel distribusi frekuensi data berikut ini:

Tabel 1 Distribusi Frekuensi Data Pretest Kemampuan Bidding dan Playing Mini Bridge Siswa SD Negeri 004 Rambah Samo

\begin{tabular}{|c|c|c|c|}
\hline No & $\begin{array}{c}\text { Interval } \\
\text { Kelas }\end{array}$ & $\begin{array}{c}\text { Frekuensi } \\
\text { Kumulatif }\end{array}$ & $\begin{array}{c}\text { Frekuensi } \\
\text { Relatif }\end{array}$ \\
\hline
\end{tabular}

\begin{tabular}{|c|c|c|c|}
\hline 1 & $45-49$ & 2 & $12.5 \%$ \\
\hline 2 & $50-54$ & 5 & $31.25 \%$ \\
\hline 3 & $55-59$ & 5 & $31.25 \%$ \\
\hline 4 & $60-64$ & 3 & $18.75 \%$ \\
\hline 5 & $65-69$ & 1 & $6.25 \%$ \\
\hline \multicolumn{2}{|c|}{ Jumlah } & 16 & $100 \%$ \\
\hline
\end{tabular}

Berdasarkan tabel di atas, diperoleh skor tertinggi sebesar 65 dan skor terendah sebesar 45 dengan rata-rata skor (mean) sebesar 53,75. Berarti, pretest kemampuan permainan mini bridge siswa adalah $53,75 \%$ dikategorikan kurang. Untuk jelasnya distribusi frekuensi data terlihat pada grafik histogram di bawah ini:

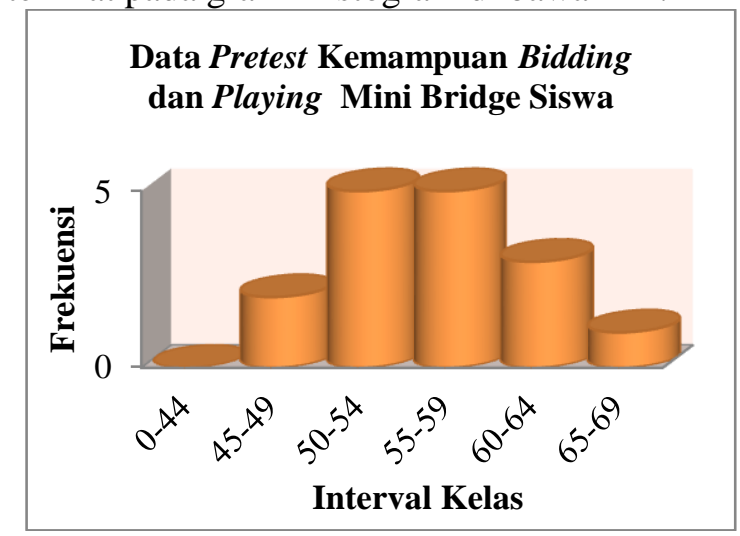

Gambar 1 Grafik Histogram Distribusi Frekuensi Data Pretest Kemampuan Bidding dan Playing Mini Bridge Siswa SD Negeri 004 Rambah Samo

Perlakuan latihan drill dalam meningkatkan kemampuan bidding dan playing mini bridge siswa diberikan selama 12 minggu dengan 2 kali pertemuan setiap minggunya. Untuk mengetahui peningkatan kemampuan permainan mini bridge yang dicapai oleh siswa diambil data posttest pada tanggal 29 Juni 2019 yang tertera pada tabel distribusi frekuensi data berikut ini:

Tabel 2 Distribusi Frekuensi Data Posttest Kemampuan Bidding dan Playing Mini Bridge Siswa SD Negeri 004 Rambah Samo

\begin{tabular}{|c|c|c|c|}
\hline No & $\begin{array}{c}\text { Interval } \\
\text { Kelas }\end{array}$ & $\begin{array}{c}\text { Frekuensi } \\
\text { Kumulatif }\end{array}$ & $\begin{array}{c}\text { Frekuensi } \\
\text { Relatif }\end{array}$ \\
\hline 1 & $70-74$ & 4 & $25 \%$ \\
\hline 2 & $75-79$ & 5 & $31.25 \%$ \\
\hline 3 & $80-84$ & 4 & $25 \%$ \\
\hline
\end{tabular}



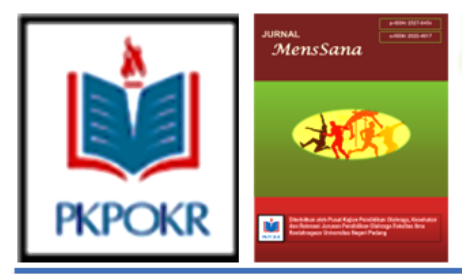

Jurnal MensSana

Vol. 4, No. 2; Tahun 2019

ISSN : 2527-645X, E-ISSN: 2622-4917

Penerbit:

Pusat Kajian Pendidikan Olahraga, Kesehatan dan Rekreasi,

Jurusan Pendidikan Olaharga, Fakultas Ilmu Keolahragaan, Universitas Negeri Padang

\begin{tabular}{|c|c|c|c|}
\hline 4 & $85-89$ & 2 & $12.5 \%$ \\
\hline 5 & $90-94$ & 1 & $6.25 \%$ \\
\hline \multicolumn{2}{|c|}{ Jumlah } & 16 & $100 \%$ \\
\hline
\end{tabular}

Berdasarkan tabel di atas, diperoleh skor tertinggi sebesar 90 dan skor terendah sebesar 70 dengan rata-rata skor (mean) sebesar 77,19. Berarti, Posttest kemampuan permainan mini bridge siswa adalah $77,19 \%$ dikategorikan cukup baik. Untuk jelasnya distribusi frekuensi data terlihat pada grafik histogram di bawah ini:

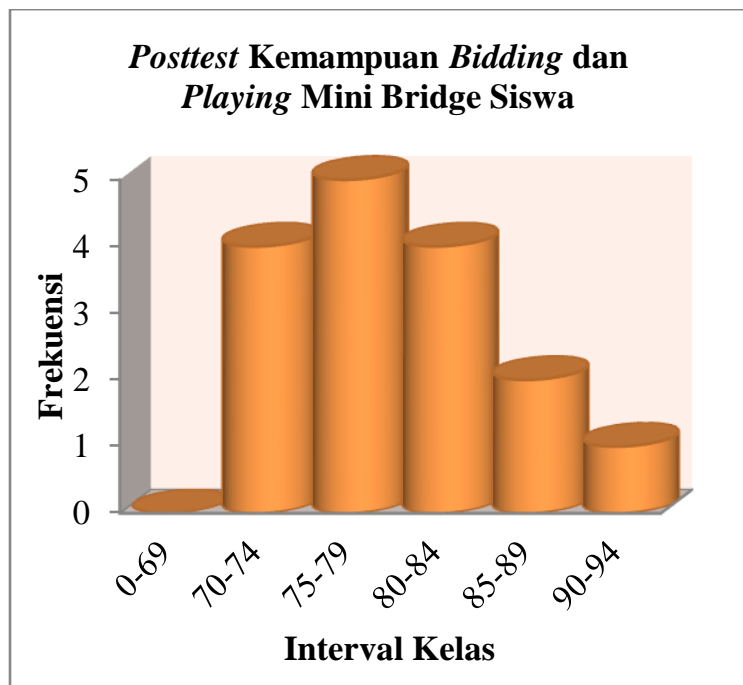

\section{Gambar 2 Grafik Histogram Distribusi Frekuensi Data Posttest Kemampuan Bidding dan Playing Mini Bridge Siswa SD Negeri 004 Rambah Samo}

Hasil analisis yang dilakukan dengan memakai uji t berpasangan diajukan Ho adalah tidak terjadinya peningkatan dalam penerapan latihan drill terhadap kemampuan bidding dan playing mini bridge siswa SD Negeri 004 Rambah Samo sedangkan Ha adalah terjadinya peningkatan terjadinya peningkatan dalam penerapan latihan drill terhadap kemampuan bidding dan playing mini bridge siswa SD Negeri 004 Rambah Samo. Dasar pengambilan keputusan adalah diterima Ho jika t hitung $<\mathrm{t}$ tabel dengan signifikan 0.05 dan diterima $\mathrm{Ha}$ jika $\mathrm{t}$ hitung $>\mathrm{t}$ tabel dengan sinigfikan 0.05. Untuk jelasnya terlihat pada tabel berikut:

Tabel 3. Hasil Uji t-tes Penerapan Metode Drill untuk Meningkatkan Kemampuan Bidding dan Playing Mini Bridge Siswa SD Negeri 004 Rambah Samo

\begin{tabular}{|c|c|c|c|c|c|}
\hline \multicolumn{2}{|c|}{ Mean } & \multirow{2}{t}{$\begin{array}{c}\mathrm{t} \\
\text { hitung }\end{array}$} & df & $\begin{array}{c}\mathrm{t} \text { tabel } \\
\alpha 0.05\end{array}$ & \multirow{2}{*}{ Kesimpulan } \\
\hline Pretest & Posttest & hignifikan \\
\hline 5
\end{tabular}

Berdasarkan tabel di atas, $\mathrm{t}$ hitung diperoleh sebesar 18,486 sedangkan $t$ tabel sebesar 1,753, maka $\mathrm{t}$ hitung $>\mathrm{t}$ tabel yaitu 18,486 > 1,753, berarti, Ho ditolah dan $\mathrm{Ha}$ diterima. Disimpulkan, terjadinya peningkatan perlakuan penerapan metode drill terhadap kemampuan bidding dan playing mini bridge siswa SD Negeri 004 Rambah Samo.

Hasil penelitian diperoleh terjadinya peningkatan kemampuan bidding dan playing mini bridge siswa setelah memberikan perlakuan penerapan metode drill. Peningkatan terjadi dapat dilihat dari nilai rata-rata pretest sebesar 53,75 menjadi nilai rata-rata posttest sebesar 77,19 yang lebih jelasnya tertera pada tabel di bawah ini:

Tabel 5.4 Peningkatan Penerapan Metode Drill terhadap Kemampuan Bidding dan Playing Mini Bridge Siswa SD Negeri 004 Rambah Samo

\begin{tabular}{|c|c|c|c|}
\hline \multicolumn{2}{|c|}{ Mean } & \multirow{2}{*}{ Selisih } & Keterangan \\
\hline Pretest & Posttest & & Terjadi \\
53,75 & 77,19 & 23,44 & $\begin{array}{c}\text { Teningkatan } \\
\text { Peningan }\end{array}$ \\
\hline
\end{tabular}

Berdasarkan tabel di atas, diperoleh peningkatan kemampuan bidding dan playing mini bridge siswa sebesar 23,44 dari nilai kemampuan sebesar 53,75 menjadi sebesar 77,19 dari perlakuan penerapan metode drill yang dilakukan. Untuk lebih jelasnya tabel di atas tertera pada gambar di bawah ini:

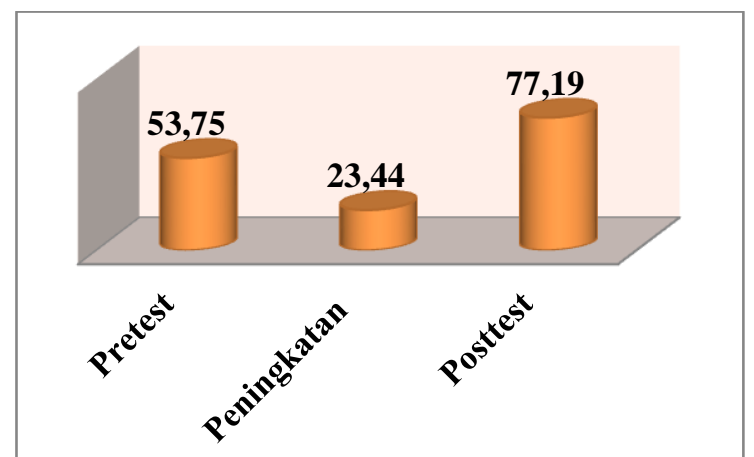

Gambar 3 Grafik Histogram Peningkatan Aplikasi Pendekatan Active Learning terhadap Kemampuan Permainan Mini Bridge Siswa 

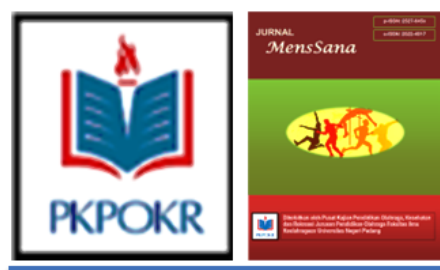

Kelas

Vol. 4, No. 2; Tahun 2019

ISSN : 2527-645X, E-ISSN: 2622-4917

Penerbit:

Pusat Kajian Pendidikan Olahraga, Kesehatan dan Rekreasi,

Jurusan Pendidikan Olaharga, Fakultas Ilmu Keolahragaan, Universitas Negeri Padang

\section{Pembahasan}

Kemampuan bidding yang baik sangat didukung oleh pengetahuan dan pemahaman akan tingkatan bidding. Bidding mini bridge terdiri dari tidak game dan game. Bidding mini bridge tidak game diantaranya $1 \mathrm{NT}, 1 \mathrm{~S}, 1 \mathrm{H}, 1 \mathrm{D}$, dan $1 \mathrm{C}$, sedangkan bidding mini brigde game adalah 4NT, 4S, 4H, 5D dan 5C. maka dari itu, siswa perlu mengetahui dan menghafal tingkatan bidding dalam menentukan kontrak main mini bridge.

Keputusan yang diperoleh dalam bidding terhadap kontrak main dilanjutkan dengan playing. GABSI (2015) mengemukan "Pada playing, si pemenang kontrak akan berusaha memenangkan trick sejumlah kontrak yang telah ia tawarkan saat bidding, sedangkan lawannya akan berupaya mencegah hal itu terjadi. Pada intinya, dalam playing sama sama berusaha memperoleh jumlah trick sesuai kontrak main.

Penerapan metode drill yang diberikan meningkatkan kemampuan bidding dan playing mini bridge siswa. Latihan diberikan dimulai dari kartu pegangan pada kontrak main terendah yaitu 1C sampai dengan kontrak main tertinggi yaitu 4 NT dan memainkannya untuk memperoleh trick sesuatu kontrak main. Pemberian latihan sesuai tingkatan bidding bertujuan untuk memberikan pemahaman dalam menetapkan kontrak main sesuai kartu pegangan.

\section{KESIMPULAN (5\%)}

Bidding atau penawaran adalah bagian penting dalam permainan bridge. GABSI (2015) menyatakan "Bidding atau Penawaran dimulai oleh dealer (si pembagi kartu) dan kesempatan berikutnya diteruskan oleh pemain sebelah kirinya berputar searah jarum jam.

Tujuan dari bidding adalah memperebutkan siapa yang berhak menjadi pemenang kontrak, pemain yang berani menawarkan diri mengumpulkan trick paling banyak adalah pemenang kontrak". Berarti, bidding merupakan suatu proses penawaran dalam memenangkan kontrak main permainan bridge.

\section{Rambah Samo}

Bagi setiap pemain menghafal tingkatan bidding itu penting. Hafalan tingkatan bidding akan membantu pemain dalam menganalisa kartu pegangan pada proses penawaran untuk mengambil keputusan dalam menentukan kontrak main.

Kegiatan penelitian yang dilakukan dapat disimpulkan, bahwa terjadinya peningkatan penerapan metode drill untuk meningkatkan kemampuan bidding dan playing mini bridge siswa SD Negeri 004 Rambah Samo sebesar 23,44\%..

\section{DAFTAR PUSTAKA}

Asbi, Taufik. (2010). Belajar Bridge. Jakarta: GABSI.

Hardianto, (2012). Belajar dan Pembelajaran. Pasir Pengaraian: UPP Press.

Istarani. (2012). Kumpulan 40 Metode Pembelajaranuntuk Revolusi Pengajaran, Medan: Media Persada

Depdiknas. 2003. Penelitian Tindakan Kelas. Bahan Ajar Pembekalan Guru Bantu

GABSI. (2015). Mini Bridge. Jakarta.

Jurnal Pendidikan Jasmani Indonesia, Volume 7 Nomor 2 Tahun 2010: Jurusan Pendidikan Olahraga Fakultas Ilmu Keolahragaan Universitas Negeri Yogyakarta.

Maolani, Rukaesih A, Ucu Cahyana. (2015) Metodologi Penelitian Pendidikan, Jakarta: PT RajaGrafindo Persada.

Sudjana. (1992). Metode Statistika. Bandung: Tarsito. 